\title{
Programlama Öğretim Sürecinde Üstün Yetenekli İlkokul Öğrencilerinin Görüsslerinin İncelenmesi ${ }^{1}$
}

\begin{tabular}{|c|c|c|}
\hline $\begin{array}{l}\text { MAKALE TÜRÜ } \\
\text { Araştırma Makalesi }\end{array}$ & $\begin{array}{c}\text { Başvuru Tarihi } \\
\text { 3.10.2018 }\end{array}$ & $\begin{array}{c}\text { Erken Görünüm Tarihi } \\
\text { 13.1.2019 } \\
\end{array}$ \\
\hline \multicolumn{3}{|c|}{$\begin{array}{c}\text { Hatice Yıldız Durak iD }{ }^{2} \\
\text { Bartın Üniversitesi }\end{array}$} \\
\hline \multicolumn{3}{|c|}{$\begin{array}{c}\text { Tolga Güyer iD } \\
\text { Gazi Üniversitesi }\end{array}$} \\
\hline \multicolumn{3}{|c|}{ Öz } \\
\hline \multicolumn{3}{|c|}{$\begin{array}{l}\text { Programlama etkinliklerinin erken yaşta deneyimlenmesi gün geçtikçe önem kazanan bir } \\
\text { konudur. Bu çalışmada ilkokul 2., 3. ve } 4 \text {. sınıfta öğrenim gören } 26 \text { üstün yetenekli öğrenci ile } \\
\text { Scratch destekli programlama öğretimine yönelik } 15 \text { haftalı bir uygulama gerçekleştirilmiştir. } \\
\text { Bu süreçte toplanan katılımcı görüşleri incelenerek katılımcıların programlama öğretim } \\
\text { sürecine ilişkin görüşleri, katılım ve güdülenme durumunun belirlenmesi amaçlanmıştır. } \\
\text { Durum çalışması kullanılan bu araştırmada nitel verileri toplamak için kişisel bilgiler ve bilişim } \\
\text { teknolojileri kullanım durumunun saptanmasıyla ilgili bir anket, yarı yapılandırılmış bireysel } \\
\text { görüşme formu, alan notları ve öğrenci yansıma raporları kullanılmıştır. Araştırmada öne çıkan } \\
\text { sonuçlardan biri Scratch programının da görsellik, renk ve ses öğelerinin güdülenme ve derse } \\
\text { katıllım üzerinde olumlu etkisi olduğudur. Ayrıca dersin başında bilgisayar dersi için olumsuz } \\
\text { tutuma sahip öğrencilerin süreç sonunda tutumlarının değiştiği görülmüştür. Öğrencileri } \\
\text { yönlendiren güdülenme türlerine bakıldığında içsel ve dişsal güdülenme unsurlarının } \\
\text { öğrenenlerin katıllım ve derse yönelik görüşleri üzerinde benzer etkileri olduğu görülmüştür. }\end{array}$} \\
\hline
\end{tabular}

Anahtar sözcükler: Üstün yetenekli öğrenciler, Scratch; K-12'de programlama, katılım, güdülenme.

\footnotetext{
${ }^{1} \mathrm{Bu}$ çalışma, Gazi Üniversitesi Eğitim Bilimleri Enstitüsü Bilgisayar ve Öğretim Teknolojileri Eğitimi Bölümü’nde, Hatice Durak tarafindan Prof. Dr. Tolga Güyer'in danışmanlığında tamamlanan, “Üstün yetenekli öğrencilere yazılım geliştirme süreçlerinin öğretilmesine yönelik bir öğretim programının tasarlanması ve gelistirilmesi” adlı doktora tezinden türetilmistir.

${ }^{2}$ Sorumlu Yazar: Dr. Öğr. Üyesi, Eğitim Fakültesi, Bilgisayar ve Öğretim Teknolojileri Eğitimi Bölümü, Eposta:hatyil05@gmail.com, https://orcid.org/0000-0002-5689-1805

${ }^{3}$ Prof. Dr., Eğitim Fakültesi, Bilgisayar ve Öğretim Teknolojileri Eğitimi Bölümü, E-posta: tguyer@gmail.com, https://orcid.org/0000-0001-9175-5043
} 
Günümüzde, programlama becerileri, bireyleri gelecek kariyerlerine daha iyi hazırlamak için önemli görülmektedir. Bu nedenle, farklı yaş gruplarına programlama eğitimleri düzenlenmektedir (Popat ve Starkey, 2019; Topalli ve Cagiltay, 2018). Alanyazın incelendiğinde özellikle erken yaşta programlama eğitimlerinin verilmesinin, bilgisayar bilimi dışındaki alanlara da katkı sağlayacak bir dizi öğrenme sonucu sağladığı vurgulanmıştır (Kalelioğlu, 2015; Moreno-León ve diğ., 2016; Resnick ve diğ., 2009; Wing, 2006).

Programlama eğitimi yaratıcılık, eleştirel düşünme, problem çözme, iletişim ve işbirliği, sosyal-kültürlerarası beceriler, üretkenlik, liderlik ve sorumluluk gibi 21 . yüzyıl becerileri olarak adlandırılan becerilerin kazandırılması ve bilgiişlemsel düşünmenin geliştirilmesinde anahtar olarak görülmektedir (Einhorn, 2011; Grover ve Pea, 2013; Lau ve Yuen, 2011; Yen, Wu ve Lin, 2012; Y1ldız-Durak ve Güyer, 2018). Öte yandan çağımızda bilgisayarlarla etkileşim her geçen gün artmaktadır (Manovich, 2013). Bilgisayarlar ve çeşitli programlarla çevrili olan bir dünyada karşılaşılan problemleri anlamak ve çözüm üretmek için "bilgisayarca" davranmak önemli olmuştur. Bireylerin günlük yaşama yönelik etkinliklere katılabilmesi için bilgisayar dilini bilmeleri ve kod okuryazarlığına sahip olmaları gerekir (Rushkoff, 2010).

Programlamaya verilen önem eğitim uygulamalarına ve politika belgelerine de yansımıştır (Popat ve Starkey, 2019). 2010'dan bu yana, Estonya, Yunanistan, İngiltere ve Avustralya'daki K-12 programında bilgisayar programlamaya yer veilmiştir (Albion, 2016; Balanskat ve Englehart, 2014). Örneğin, National Research Council (2012) bilgisayar bilimi eğitimi için sunduğu K-12 çerçevesinde programlama eğitimine değinmiştir.

Wing (2006) programlama bilgi ve becerilerini, herkesin öğrenmesi gereken 21. yüzyıl yetkinlikleri olarak tanımlar. Programlama; okuma, yazma ve matematik ile birlikte erken yaşta öğrenilmesi gereken temel bir analitik beceri olarak tanımlanmaktadır (Grover ve Pea, 2013; Lye ve Koh, 2014). Bununla birlikte alanyazında çok sınırlı sayıda çalışmada üstün yeteneklilerin programlama öğretimine ilişkin sonuçlara yer verilmiştir. Buradan hareketle üstün yeteneklilere yönelik çalışma sonuçlarıyla ilgili alanyazında boşluklar olduğu söylenebilir.

$\mathrm{Bu}$ araştırmada ilkokullarda üstün yetenekli öğrencilerin programlama öğrenmesine yönelik bir çalışma yapılmasına karar verilmiştir. Mevcut çalışmada üstün yetenekli öğrencilerin seçilmesinin ise özel nedenleri vardır. Üstün yetenekli öğrencilerin eğitiminde, öğrenim ortamının daha karmaşı ve gerçek dünya sorunlarını keşfetmeye, yenilikçi ürünler yaratmaya ve daha yüksek düzeyli düşünme becerilerini öğrenmeye yetecek firsatlar sağlaması gerekir (Poftak, 1988; Renzulli ve Reis, 1997; Tomlinson, 2002). Bu öğrenme koşullarını sağlamak için programlama etkinliklerinin etkili bir yol olduğu düşünülmektedir. Nitekim programlama öğretiminin doğası, üstün yetenekli öğrencilerin gereksinim duyduğu eğitsel çevrenin doğası ile benzerlik göstermektedir (Yildiz-Durak ve Güyer, 2018). Scratch ise programlama sürecinde üstün yetenekli öğrencilerin programlama ile ilgili soyut 
bilgilerini daha kolay öğrenmelerine yardımcı olabilir. Alanyazında Scratch ile gerçekleştirilen programlama etkinliklerinin üstün yetenekli ögrencilerin problem çözme ve mantıksal düşünme gibi çeşitli düşünme becerilerinin gelişimine katkı yaptığı vurgulanmaktadır (Siegle, 2009). Ayrıca üstün yetenekli öğrencilerin kendi bilgisini özgün bir şekilde oluşturma eğilimleri göz önünde bulundurularak (VanTassel-Baska, 1988), Scratch ile bireysel proje çalışması yapmaları desteklenmiştir.

Programlama, öğrenciler için algılanması ve öğrenilmesi zor bir konudur (Havenga ve Mentz, 2009; Hongwarittorrn ve Krairit, 2010; Koorsse, Cilliers, ve Calitz, 2015). Programlamaya yönelik algılanan bu zorluğun, eğitim sürecinde öğrencilerin programlama etkinliklerine katılımının, başarı ve güdülenmenin zamanla azalmasına neden olduğu görülmüştür (Altun ve Mazman, 2012; Kim, Song, ve Lee, 2009). Katılım, güdülenme ve öğrenme performansı arasında güçlü bir ilişki olduğu (Fredricks, Blumenfeld ve Paris, 2004; Yıldız-Durak, 2018a) göz önüne alınarak mevcut çalı̧̧mada üstün yetenekli öğrencilerin programlama öğrenme sürecindeki katılım ve güdülenme ile ilgili görüşlerinin ele alınması önemli ve yararlı görülmüştür.

\section{Programlama Öğretiminde Katılım ve Katılımın Boyutları}

Aktif öğrenme kuramına göre katılım, öğrenme için gerekli bir ön koşul olarak kabul edilir (Fredricks, Blumenfeld, ve Paris, 2004). Katılımın özellikle öğrenme ortamlarında akademik performans üzerinde önemli bir etkisi vardır (Azevedo, 2015). Programlama gibi zor olarak algılanan bir konuda öğrenme performansının geliştirilmesi açısından derse aktif katılım sağlanmalıdır (Altun ve Mazman, 2012). Çünkü programlama, problem çözme, akıl yürütme, çeşitli bilişsel beceriler gibi birçok beceriyi geliştiren ve bilişsel, duyuşsal ve davranışsal katılımı birlikte gerektiren karmaş̧ı bir süreçtir (Jenkins, 2002). Bloom (1976) öğrenci katılımını, öğrencinin istenen davranışı kazanması için kendine sunulan öğrenme durumlarının öğeleriyle etkileşmesi ve bu etkileşimi davranışı kazanıncaya kadar sürdürmesi olarak belirtmektedir.

Programlama öğrenmenin, bireyin aktif katılımı ile daha verimli bir biçimde gerçekleşecektir (Yildiz-Durak, 2018a; Yildiz Durak, 2018b). Fredrick, Blumenhfeld ve Paris (2004) öğrenci katılımını üç alt boyutta incelemiştir. Bunlar: davranışsal, duyuşsal ve bilişsel katılım türleridir. Fredrick, Blumenhfeld ve Paris (2004) katılım türlerini şu şekilde açıklamaktadır:

Davranışsal katılım, öğrencilerin derse devam durumunu ve etkinliklere aktif şekilde katılmalarını içerir.

Duyuşsal katılım, etkinliklere aktif olarak katılma sürecine ilişkin istekliliği içerir. 
Bilişsel katılım, etkinliklerde öğrencinin öğrenmeye yönelik çabasını içermektedir. Katılım öğrencinin fiziksel olarak sınıfta bulunsa da bilişsel ve duyuşsal bulunma durumunun sağlanmasını gerektirir (Harper ve Quaye, 2009).

\section{Programlama Öğretiminde Güdülenme ve Güdülenmenin Boyutları}

Güdülenme insanı davranışa iten, bu davranışların hızı, şiddeti ve sürekliliğini belirleyen ve yönlendiren temel bir etkendir. Güdülenme öğrenme için anahtar bir değişkendir (Fairchild, Horst, Finney ve Barron, 2005; Ryan ve Deci, 2000). Özellikle üstün yetenekli öğrenciler için oluşturulan öğrenme çevrelerinde güdülenme kavramı daha da önem kazanmaktadır. Öyle ki aynı yeteneğe aynı düzeyde sahip olan üstün yetenekli öğrencilerin 'güdülenme düzeyleri' bakımından farklılık göstermeleri, farklı düzeyde öğrenme performansı göstermelerine neden olmaktadır (Reis ve Renzulli, 2009; Tomlinson vd., 2008). Öte yandan, üstün yeteneklilere özel tasarlanmayan öğrenme çevrelerinde öğrencilerin bilişsel ve ilgi düzeyi açısından doyum sağlamaları zorlaşmaktadır. Bu da doğrudan güdülenmelerini etkilemektedir (Renzulli ve Park, 2000). Üstün yetenekli öğrencilerin bireysel potansiyellerini geliştirmelerine olanak tanıyan öğrenme çevreleri tasarlanmadığında bu öğrencilerin uyum sorunu, terk etme, dışlanma gibi olumsuz durumlar yaşamaları kaçınılmazdır (Hansen ve Toso, 2007).

Güdülenmenin farklı çeşitleri bulunmaktadır (Ryan ve Deci, 2000). Bu çalışmada güdülenmenin içsel (intrinsic) ve dışsal (extrinsic) boyutları ve bu boyutlar üzerine deneyimler incelenmiştir.

Íçsel güdülenme: Öğrencinin dişsal bir ödül olmadan kendi öğrenmesinden zevk alması ve doyuma ulaşmasıdır. Ryan ve Deci'ye (2000) göre içsel güdülenme " 'bilişsel, sosyal ve psiko-motor gelişimde kritik bileşendir çünkü kişinin doğasındaki bilgi ve becerilerden harekete geçer”. Bu nedenle içsel güdülenme oldukça karmaşık bir yapıdadır.

Dışsal güdülenme: Cezadan kaçma, yarış, ödül alma, iyi not alma, öğretmen, aile, arkadaş gibi kişilerin olumsuz görüşlerinden kaçma dişsal durumlarla ilgilidir (Middleton ve Spanish, 1999).

Güdülenme, birçok durumda özellikle de başlangıçta olumsuz tutum geliştirdikleri, zor olarak gördükleri programlama gibi derslerde özellikle ihmal edilmemesi gereken bir değişkendir. Programlama öğreniminde öğrencinin etkin şekilde bilişsel ve duyuşsal olarak uygulamanın içinde bulunması ve etkinliklerde sürekliliğinin sağlanması önemlidir. Ayrıca Law, Lee ve Yu’ya (2010) göre güdülenme ve programlama öğrenmenin sıkı bir ilişkisi olduğu ve programlama becerisinin kazanılmasında öğrenenin yeterince güdülenmemesi durumunda öğretimin olanaksız olacağı vurgulanmıştır.

\section{Araştırmanın Amacı}

$\mathrm{Bu}$ araştırmada amaç, ilkokul 2., 3. ve 4. sınıflarında öğrenim gören üstün yetenekli öğrencilere Scratch destekli programlama süreçlerinin öğretilmesine yönelik tasarlanmış bir öğretim sürecine ilişkin öğrenci görüşlerini incelemektir. 
$\mathrm{Bu}$ amaç doğrultusunda araştırma soruları şu şekilde belirlenmiştir:

1. Programlama süreçlerinin öğretilmesine yönelik öğretim programının uygulama sürecinde öğrenenlerin programlamaya yönelik görüşleri nasıldır?

2. Programlama süreçlerinin öğretilmesine yönelik öğretim programının uygulama sürecinde öğrenenlerin derse katılımı (davranışsal, duyuşsal ve bilişsel katılım) nasıldır?

3. Programlama süreçlerinin öğretilmesine yönelik öğretim programının uygulama sürecinde öğrenenlerin güdülenme durumunu etkileyen etmenler nelerdir?

\section{Yöntem}

Bu bölümde çalımanın yöntemi, uygulama grubu ve uygulama süreciyle ilgili ayrıntılara yer verilmiştir.

\section{Araştırma Modeli}

Bu araştırmada Scratch destekli programlama süreçlerinin öğretilmesine yönelik öğretim sürecine ilişkin katılımcı görüşlerini derinlemesine incelemek amacıyla nitel araştırma yöntemlerinden durum çalışması kullanılmışıtır. Yin'e (2003) göre durum çalışmaları güncel bir olguyu kendi doğal yaşam çerçevesinde anlamaya çalışan, olgu ve içinde bulunduğu içerik arasındaki sınırların kesin hatlarıyla belirgin olmadığı ve çoklu kanıt veya veri kaynağının mevcut olduğu durumlarda kullanılır.

\section{Çalışma Grubu ve Araştırma Ortamı}

Bu çalışma 2014-2015 eğitim öğretim yılı bahar döneminde ilkokul 2., 3. ve 4. sınıfta öğrenim gören destek eğitim odası uygulamasıyla ders dışı eğitim almasına karar verilen 26 öğrenci ile yapılmıştır. Çalışma grubunu oluşturan Ankara'da bir ilkokulda öğrenim gören bu öğrenciler daha önce Rehberlik ve Araştırma Merkezi’nde üstün yetenekli öğrencileri tanılamaya yönelik testlerde yeterli puanı alarak üstün yetenekli olarak tanılanmıştır. Çalışma grubunun özellikleri Tablo 1'de sunulmuştur.

Tablo 1

Çalışma Grubunun Özellikleri

\begin{tabular}{lllll}
\hline & Katılımcılar & f & $\%$ \\
\hline \multirow{3}{*}{ Cinsiyet } & \multirow{2}{*}{ Kadın } & $\begin{array}{l}\text { P1-1, P1-2, P1-4, S1-1, S1-2, S1-7, S1-8, S2-3, } \\
\text { S2-4, S2-5, S2-6, S3-2, S3-4, S3-6 }\end{array}$ & \multirow{2}{*}{53.8} \\
\cline { 2 - 5 } & \multirow{2}{*}{ Erkek } & $\begin{array}{l}\text { P1-3, P1-5, P1-6, S1-3, S1-4, S1-5, S1-6, S2-1, } \\
\text { S2-2, S3-1, S3-3, S3-5 }\end{array}$ & \multirow{2}{*}{46.2} \\
\hline
\end{tabular}


Tablo 1 (devam)

\begin{tabular}{lllll}
\hline & \multicolumn{1}{c}{ Katılımcılar } & f & \% \\
\hline \multirow{4}{*}{ Sinıf } & \multirow{2}{*}{ 2. Sinıf } & $\begin{array}{l}\text { S1-1, S1-2, S1-3, S1-4, S1-5, S1-6, S1-7, S1-8, } \\
\text { S3-1, S3-2 }\end{array}$ & \multirow{2}{*}{38.5} \\
\cline { 2 - 5 } & 3. Sinıf & $\begin{array}{l}\text { P1-1, P1-2, P1-3, P1-4, P1-5, P1-6, S2-1, S2-2, } \\
\text { S2-3, S2-4, S3-3, S3-4 }\end{array}$ & \multirow{2}{*}{46.1} \\
\cline { 2 - 6 } & 4. Sinıf & S2-5, S2-6, S3-5, S3-6 & 4 & 15.4 \\
\hline \multirow{4}{*}{ Yaş } & 7 yaş & P1-6, S1-3, S1-4, S1-5 & 4 & 15.4 \\
\cline { 2 - 6 } & 8 yaş & S1-1, S1-2, S1-6, S1-7, S1-8, S3-1, S3-2, S3-4 & 8 & 30.8 \\
\cline { 2 - 6 } & 9 yaş & $\begin{array}{l}\text { P1-1, P1-2, P1-3, P1-4, P1-5, S2-1, S2-2, S2-3, } \\
\text { S2-4, S3-3, S3-6 }\end{array}$ & \multirow{2}{*}{42.3} \\
\cline { 2 - 6 } & 10 yaş & S2-5, S2-6, S3-5 & 3 & 11.5 \\
\hline
\end{tabular}

*Katılımcı kodları katılımcıların dersi aldığı gün (Pazartesi: P, Salı: S) o gün içindeki grup sayısı/sırasın ve o gruptaki öğrencilerinin isimlerinin alfabetik sıralandığındaki liste sırasını göstermektedir.

Tablo 1'de görüldüğü gibi katılımcıların \%53.8'i kadın \% 46.2'si erkek; \% 38.5'inin 2. sinıf, \% 46.1'inin 3. sinıf ve \% 15.4'ünün 4. sinıf olduğu görülmektedir. Katılımcıların \% 42.3'ü 9 yaşındadır. \% 30.8'i 8 yaşında, \% 15.4'ü 7 yaşında, \% 11.5'i ise 10 yaşındadır.

Belirtilen özelliklere sahip çalışma grubu ile 15 hafta süren bir uygulama araştırmacılar tarafindan gerçekleştirilmiştir. Uygulama öncesinde öğrencilerin çevrim-içi ortamdan faydalanabilmesi için 4 haftalık bir uyum eğitimi yapılmıştır. Bu süre içinde öğrencilerin ortama kaydolmaları sağlanmış ve ortamı kullanma konusunda deneyim kazanmaları desteklenmiş̧ir. Şekil 1'de çevrim-içi uygulama ortamından bir arayüz sunulmuştur.

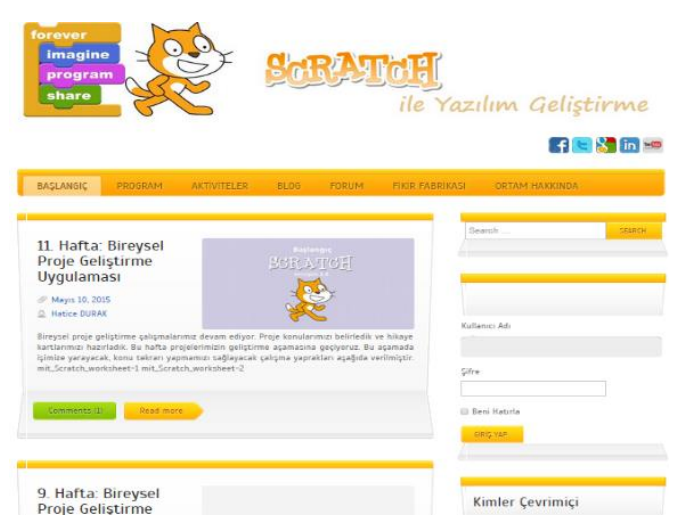

Şekil 1. Çevrim-içi ortam arayüzü-anasayfa. 
Uygulama süresince, Bilişim Teknolojileri (BT) sınıfında yüz yüze işlenen derslerin yanı sıra çevrim-içi öğrenme ortamı kullanılmıştır. Şekil 1'de arayüzü sunulan ortamda öğrenenler ders öğretmeni tarafından üye yapılmış ve ortamdan her hafta konularla ilgili çalışma yaprakları ve ders dışı etkinlikler paylaşılmıştır.

\section{Veri Toplama Araçları}

$\mathrm{Bu}$ çalışmada nitel verileri toplamak için çeşitli veri toplama araçları kullanılmıştır.

Kişisel bilgiler, bilgisayar ve internet kullanım durumu anketi. Bu ankette öğrencilerin cinsiyet, yaş, sınıf, anne, baba eğitim durumu, gelir durumu ve kardeş sayısı gibi demografik bilgilerini toplamak için 7 soruluk kişisel bilgiler bölümü oluşturulmuştur. Öğrencilerin bilgisayar ve internet kullanım durumlarını belirlemek için ilgili ankette 9 sorudan oluşan bilişim teknolojileri kullanım bilgileri bölümüne yer verilmiştir.

Bireysel görüşme formu. Öğrencilerden, yazılım geliştirme süreçlerinin öğretimi sürecinin tasarımıyla ilgili görüşleri alınmıştır. Görüşme formunda problem tabanlı uygulamalarla ilgili 10, proje geliştirme süreciyle ilgili 6 açı uçlu soru yer almaktadır. Hazırlanan görüşme formunun geçerliği için beş uzmanın görüşüne başvurulmuştur. Uzmanlardan formda yer alan maddelerin kapsamı-içeriği yansıtma durumunun uygunluğu için görüș bildirmeleri istenmiștir. $\mathrm{Bu}$ uzmanların dördü Bilgisayar ve Öğretim Teknolojileri bölümünde doktorasını tamamlamıştır. Uzmanların biri ise üstün yetenekli öğrencilerin tanılanması ve eğitimiyle ilgili çalışmalar yürüten, Psikolojik Danışma ve Rehberlik bölümü yüksek lisans mezunu bir Rehberlik ve Araştırma Merkezi rehberlik öğretmenidir. Uzman görüşlerine göre sorularda yer alan ifadeler düzenlemiştir. Ayrıca uzmanlar görüşme sorularının daha ayrıntılı olması konusunda öneride bulunmuştur.

Alan notları. Haftalık alan notları tutularak öğrenme ortamında gelişen olayların ayrıntıları, öğrenme ortamında ortaya çıkan kişisel tepkiler, ortamı yansıtacak özgün kelimeler, konuşma özetleri kayıt altına alınmıştır. Öğretimi gerçekleştiren araştırmacı her dersi ders sonunda ayrıntılı şekilde raporlamıştır.

Öğrenci yansıma raporu. Öğrenenlerden dönem boyunca öğrendiklerini, öğrenme süreçlerinin güçlü ve zayıf yanlarını, nasıl geliştirilebileceğini ve öğrenme deneyimlerini açıkladığı bir sayfalık dönem sonu yansıma raporları yazmaları istenmiş̧tir.

Veri toplama araçlarının uygulama sürecinde kullanım zamanlarına ilişkin bilgiler Tablo 2'de verilmiştir. 
Tablo 2

Veri Toplama Araçlarının Haftalara Göre Uygulama Planı

\begin{tabular}{l} 
Veri Toplama Araçları \\
Kişisel Bilgiler, BT \\
Kullanım Durumu Anketi \\
Görüşme Formu \\
Alan Notları \\
\hline Öğrenci Yansima Raporu
\end{tabular}

Tablo 2 incelendiğinde alan notlarının her hafta tutulduğu, görüşme formlarının 2 haftada bir, Kişisel Bilgiler, BT Kullanım Durumu Anketi'nin uygulamanın ilk haftası, Öğrenci Yansıma Raporu'nun ise uygulamanın son haftası uygulandığı görülmektedir.

\section{Uygulama Süreci}

Araştırma kapsamında yapılan uygulama 2015 yılı bahar döneminde 15 hafta sürmüştür. Uygulama öncesinde içeriğin ve kazanımların belirlenmesi, uzman görüşlerine başvurulması, içeriğin sıralanması eğitsel materyallerin tasarlanması, uygulamanın yapılacağı bilişim teknolojileri sınıfının eksiklerinin giderilmesi ve çevrim-içi ortam uyum işlemleri gerçekleştirilmiştir. Araştırma sürecine ilişkin ayrıntılar Şekil 2'de sunulmuştur.
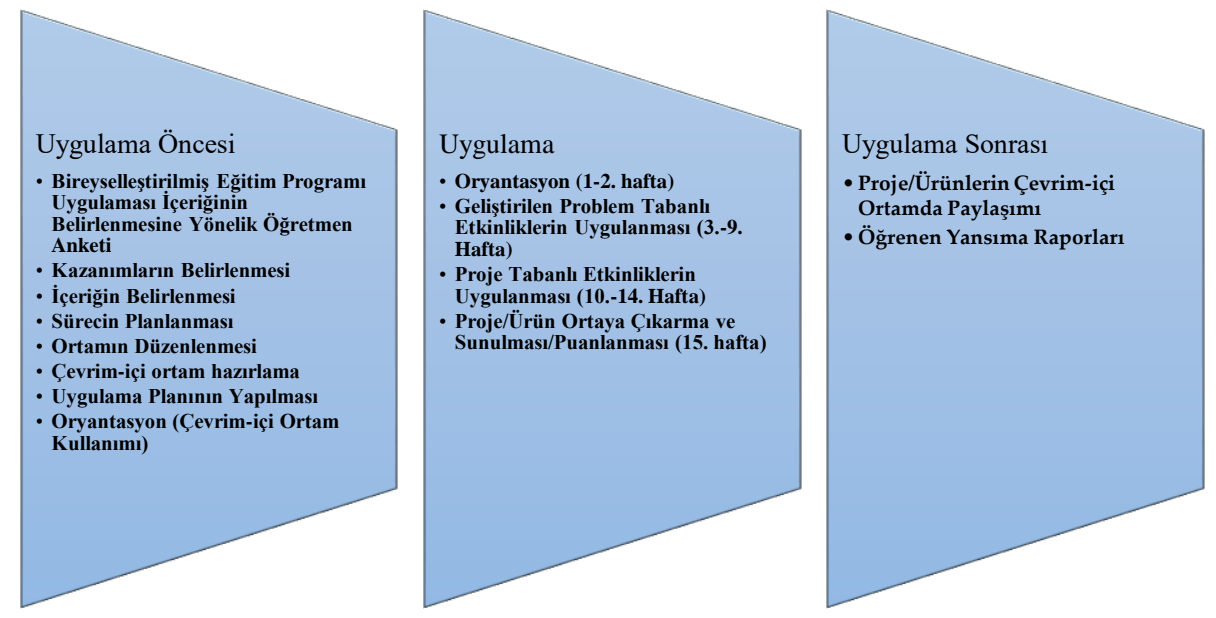

Şekil 2. Araştırma boyunca gerçekleştirilen işlerin akışı 
Şekil 2 incelendiğinde araştırmanın uygulama öncesi, uygulama süreci ve uygulama sonrası aşamalarından oluştuğu görülmektedir. Bu aşamalarda yapılan işlemler ayrıntılı olarak sunulmuştur.

\section{Verilerin Analizi}

$\mathrm{Bu}$ çalı̧̧mada nitel yöntemlerle toplanan veriler, içerik analizi yöntemi ile çözümlenmiştir. Verileri açıklayabilmek, kavram ve ilişkilere ulaşmak amacıyla içerik analizi yapılır. İçerik analizinde veriler öncelikle kavramsallaştırılır. Ortaya çıkarılan kavramlar mantıksal olarak düzenlenir ve temalar belirlenir (Yıldırım ve Şimşek, 2013). Betimsel analizde özetlenen ve yorumlanan verilerin, içerik analizinde daha derin bir işlem gerçekleştirilerek betimsel bir yaklaşımla fark edilemeyen kavram (kod) ve temalar, içerik analizi ile keşfedilebilir.

$\mathrm{Bu}$ çalışmada verilerin analizi için NVivo 11.0 paket programı kullanılmıştır. Çalışma süresince elde edilen ham veriler araştırmacı tarafindan açık kodlama yöntemi ile kodlanmıştır. Açık kodlama ile veri parçaları (cümle) sorgulanarak içinde barındırdığı anlam ortaya çıkarılmaya çalışılmıştır. Daha sonra veriler başka bir alan uzmanı tarafından açık kodlama yöntemiyle kodlanmıştır. İki analizden elde edilen sonuçlar ayrıntılı ve dikkatli bir şekilde okunarak içerdiği anlam hakkında tartışılmış ve fikir birliğinin sağlandığı ortak bir kodlama yapılmıştır. Bu doğrultuda güvenirliğin kodlama işleminde ortak bir anlayışla sağlandığı belirtilebilir (Yıldırım ve Şimşek, 2013). Nitel verilerin analizinde öncelikle araştırmacılar verileri okuyup ve üzerinde gerekli düzeltmeleri yapmıştır. Verileri genel olarak gözden geçirerek bütüncül bir bakış kazanmak için araştırmacı, ikinci bir ilgili alan uzmanı ile birlikte verileri ilk okumada yüzeysel olarak kodlamıştır. İkinci okumada muhtemel kodları belirlemişler, üçüncü okumada benzer kodları tek bir kod altına toplamışlar, dördüncü okumada kodların yer alacağı temaları saptamışlar, beşinci okumada kod ve tema uyumlarını tekrar gözden geçirerek her bir kategorinin son halini belirlemişlerdir. Bunun ardından da oluşturulan her bir kategori altındaki kod frekanslarını hesaplayarak taslak form oluşturmuşlardır. Sonra veriler, bir alan uzmanına gönderilmiştir. Bu uzman tarafından araştırmanın ham verileri kodlamıştır. İçerik analizinde oluşturulan kodlar aralarındaki ilişkilere göre kod ve tema şemaları oluşturulmuş ve bu kodlar ilgili alan uzmanı olan bir kişi tarafindan incelenmiş ve uygunluğu onaylanmıştır. Alan uzmanından gelen dönütlerden sonra araştırmacı ilk olarak uzmanın kod sayılarını belirlemiştir. Bu kod sayılarıyla ikinci alan uzmanıyla birlikte oluşturulan kod sayılarını karşılaştırmak için daha önceden oluşturulan taslak forma eklenmiştir. Daha sonra ortak, benzer ve farklı kodlar belirlenmiştir. Son aşamada araştırmacı, ilgili alan uzmanı ile bir araya gelerek benzer ve farklı kodları tartışmış, benzerlikler, tarafların da kabul edeceği ortak bir kod altında toplanmıştır. Farklı kodlarda ise araştırmanın bütününe uyan, araştırmacı ve uzman tarafindan geçerli bulunan kodlar belirlenmiştir. Bazı kodlar tamamen değiştirilmiştir. Diğerleri ise var olan ilgili kodun altına yerleştirilmiştir. Kodlama işleminin ardından iki kodlama arasındaki eşleşme oranı \% 90 olarak saptanmıştır. Bu oran puanlayıcılar arası tutarlılığı yani puanlayıcılar arası güvenirliğin sağlandığını göstermektedir. İki 
analizden elde edilen sonuçlar detaylı ve dikkatli bir şekilde okunarak içerdiği anlam hakkında tartışılmış ve her iki uzmanın kodlama sisteminde ortak bir anlayış geliştirene kadar tartışılmıştır. Kodlamalar sonucunda iki uzmanın elde ettiği kod sayıları belirlenen bu kategoriler çerçevesinde Miles ve Huberman'ın (1994, s, 64) belirttiği şu güvenirlik formülünden yararlanılarak karşılaştırılmıştır:

Güvenirlik= (görüş birliği sayısı)/(toplam görüş birliği+görüş ayrllı̆̆ sayısı)

Büyüköztürk ve diğ.'ne (2009) göre, içerik analizi sonucunda elde edilen verilerin yorumlanmasında genellikle frekans ve yüzde kullanılır. Toplanan veriler için oluş̧urulan temalar ile ilişsili kodların daha kolay yorumlanabilmesi için içerik analizinde ortaya çıkan veriler kod ve kodlanma frekansları ile sunulmuştur. Ayrıca inandırıcıllı̆̆ arttırmak için nitel analizlerde araştırmacı, her açıklamanın ve her sonucun sürekli olarak nedenlerini ve bu nedenleri destekleyici bulguları olabildiği kadar doğrudan alıntı ile sunmuştur.

\section{Araştırmanın Geçerliği ve Güvenirliği}

Geçerlik, araştırmada ulaşılan sonuçların doğruluğu ile ilgiliyken; dış geçerlik araştırma sonuçlarının benzer ortamda uygulanmasıyla benzer sonuçlara ulaşabilme durumunu kapsar. İç geçerlik araştırma sonuçlarının gerçeği yansıtmasındaki yeterliliği ile ilgilidir. İç geçerlik için araştırmada farklı kaynaklardan (görüşme, öğrenci yansımaları ve alan notları) planlanan zamanlarda veri toplanmıştır. Veri kaynakları çeşitlenmiştir. Araştırma sürecinde verilerin analiz süreci ayrıntılı şekilde açıklanmıştır. Böylece sonuçlara nasıl ulaşıldığı tüm boyutlarıyla ortaya konulmuştur. Dış geçerlik için benzer ortamlarda benzer sonuçlara ulaşılabilmesi için araştırma ortamı, katılımcıların özellikleri ve uygulama süreci ayrıntılı şekilde açıklanmıştır.

Güvenirlik ise araştırmada aynı verilerle benzer sonuçlara ulaşılıp ulaşılamayacağı ile ilgilidir (Yıldırım ve Şimşek, 2013). Bu bölümde, mevcut araştırma kapsamında geçerlik ve güvenirliği geliştirmeye yönelik yapılan çalışmalar açıklanmıştır. Güvenirlik için araştırmacı, araştırmada üstlendiği rolü açıklamıştır. Veri analizi sürecinde verilerin kodlanması bir alan uzmanı ile birlikte yapılmıştır. Araştırmacı izlediği süreci açık ve ayrıntılı tanımlamış ve araştırmayı sistemli bir şekilde aşama aşama geliştirmiştir.

\section{Bulgular}

$\mathrm{Bu}$ bölümde çalışma sürecinde elde edilen bulgular alt problemler kapsamında sunulmaktadır.

\section{Programlama Süreçlerinin Öğretilmesine Yönelik Öğretim Programının Uygulama Sürecinde Öğrenenlerin Programlamaya Yönelik Görüşleri Nedir?}

Araştırmanın ilk araştırma sorusu ile ilgili içerik analizi ile oluşturulan kodlar ve temalar Tablo 3 ve Tablo 4 'te verilmektedir. Ayrıca dikkat çekici katılımcı görüşleri kodlarla birlikte aynen sunulmuştur. 
Scratch programıyla ilgili öğrenci görüşleri. Öğrencilerin programlama sürecine bakışını ortaya koymak için öncelikle katılımcıların Scratch programına ilişkin görüşleri ve bu programı nasıl tanımladıkları ele alınmıştır. "Öğrencilerin Scratch programıyla ilgili görüşleri” teması altında yer alan kodlar ve kodlanma sıklıkları Tablo 3 'te verilmiştir.

Tablo 3

Scratch Programıyla İlgili Öğrenci Görüşleri

\begin{tabular}{llc}
\hline Temalar & Kodlar & Kodlama Sayısı \\
\hline & Farklı & 14 \\
& Öğretici & 12 \\
& Çok Yönlü & 8 \\
& Görsel/Renkli & 7 \\
Scratch Programıyla İlgili Görüşler & Kontrol Etme Esnekliği & 4 \\
& Nitelikli & 3 \\
& Karmaşı/Garip & 2 \\
& Sürprizli & 1 \\
& Olağanüstü & 1 \\
\hline
\end{tabular}

Tablo 3 incelendiğinde katılımcıların programlama öğretim sürecinde kullandıkları Scratch programını sıklıkla "farklı, öğretici ve çok yönlü” olarak tanımladıkları görülmektedir. Ayrıca uygulama boyunca öğrenenlerle yapılan görüşmelerde "Scratch hakkında ne söyleyebilirsin?" sorusu sorulduğunda öğrenenler Scratch programının görsel, renkli, kontrol etme esnekliği bulunan, nitelikli bazen de karmaşık ve garip gelen özellikleri bulunan sürprizli ve olağanüstü bir öğrenme aracı olduğunu vurgulamıştır. Öğrenenlerin ilgili konudaki görüşlerinden örnekler aşağıda sunulmuştur:

“Çok farklı ve yapboz oluşturur gibi” [P1-2].

"Çok farklı bir program olduğunu haftalar geçtikçe daha iyi anlıyorum bu hafta debug yaparken çok eğlendim bulmaca gibiydi” [ S3-2].

“Çok iyi kaliteli yapılmış farklı bir program” [ P1-3].

Öğrenenlerin bazılarının bilişim teknolojileri dersinde daha önce MS Word ve MS Powerpoint programlarını kullandığı bilinmektedir. Daha önce kullanılan bu programlar, göz önünde bulundurarak öğrenenlerin Scratch'ın farklı bir program olduğunu düşündüğü görülmektedir. Ayrıca Scratch'ın öğrenenlere farklı gelen özelliklerinin yanı sıra bu ortamın öğrencilerce öğretici bulunduğundan sözedilmiştir. $\mathrm{Bu}$ konudaki öğrenci görüşlerinden aynen alıntılar aşağıda sunulmuştur:

"Bence Scratch çok ama çok mükemmel öğretici bir program” [S3-6].

“Çok etkili öğrettiğini söyleyebilirim” [ P1-1]. 
“Güzel ve öğretici bir program” [S2-6]. $5]$.

"Eğitici tek başına herşeye yeten bir uygulama. Bizim seviyemize uygun" [S1 -

"Her hafta yeni şeyler öğrendiğimiz program. Bence scratch ile yapılacakların sinırı yok" [ S3-5].

Öğrenenler Scratch'ın eğlenceli, renkli, görsel, nitelikli olduğundan bu programı beğendiklerini belirten görüşleri ise şu şekildedir:

“Bu programı çok sevdiğimi ve çok eğlendiğimi söyleyebilirim” [S1-6].

"Animasyon ve programlama. Çok eğlenceli ve yaratıcı" [S3-1].

“Çok güzel olduğunu ve ilerledikçe daha güzel konuların çıkacağı süprizli bir program olduğunu düşünüyorum” [P1-4].

“Bir çocuk için çok güzel olduğunu söyleyebilirim” [S1-5].

"Scratch çok eğlenceli bir animasyon ve oyun programıdır" [P1-2].

"Scratch içinden sürekli aynı bebek çıkaran oyuncak gibi. Yapılacakların sınırı yok" [S1-7].

“Kullanmayı bilirsen eğlenceli ve çok yönlü” [S3-5].

"Hayallerimize göre şekillendirebileceğim bir program. Çok güzel yani. Çok iyi düşünülmüş" [S2-5].

"Çok renkli, ses ve hareket olan harika bir program" [ S1-8].

“Çok yönü olan her ders için kullanılabilecek program” [S2-5].

“O kadar güzel bir program ki nasıl yapmışlar merak ediyorum” [P1-4].

"Hayal edip, planlayıp kodladım, en sonunda paylaşacağım program” [S1-4].

“Görselliği olan bize uygulama için firsat sunan çok güzel bir program” [P1-5].

"Scratch bizi hayal kurmaya hikaye kurmaya ve bilgisayarı öğrenmeye iten program" [ S2-3].

Birkaç görüşte de Scratch programının özelliklerine yönelik şu önerilerde bulunulmuştur:

"Bazen takılıyorum. Keşke daha basit olsaydı" [S3-4].

"Paint gibi resim düzenleme ve word gibi yazı yazma bölümü olsaydı" [P1-1].

Programlama sürecine ilişkin görüşler. Öğrenenlerin programlama sürecine ilişkin görüşlerini ortaya koymak için katılımcıların derse ilişkin görüşleri ve programlamayı nasıl tanımladıkları ele alınmıştır. "Öğrencilerin programlama 
sürecine ilişkin görüşleri” teması altında yer alan kodlar ve bu kodların kodlanma sıklıkları Tablo 4'te verilmiştir.

Tablo 4

Öğrencilerin Programlama Sürecine İlişkin Görüşleri

\begin{tabular}{lll}
\hline Temalar & Kodlar & Kodlama Sayısı \\
\hline \multirow{3}{*}{$\begin{array}{l}\text { Programlama } \\
\text { Sürecine ilişkin }\end{array}$} & Scratch programının özellikleri & 167 \\
\cline { 2 - 3 } öğrenci & Farklı problem çözüm yollarının denenmesi & 26 \\
\cline { 2 - 3 } görüşleri & Programlamanın diğer derslerden farklı görülmesi & 18 \\
\cline { 2 - 3 } & Diğer derslerden daha zevkli bulunması & 7 \\
\cline { 2 - 3 } & Bilgisayara karşı tutumu değiştirmesi & 6 \\
\cline { 2 - 3 } & Programlamanın zor ve uğraştıcı olması & 5 \\
\cline { 2 - 3 } & Dersin etkinliklerinin fazla zaman alması & 3 \\
\hline
\end{tabular}

Programlama öğretiminin gerçekleştirildiği 15 hafta boyunca öğrenenlerin programlama öğrenme sürecinde programlamaya ilişkin sevdikleri yönler ve programlamaya nasıl baktıkları sorulmuştur. Tablo 4 'teki veriler dikkate alındığında, katılımcılar çoğunlukla programlama öğretim sürecini, Scratch programının özelliklerinin programlamaya yönelik görüşlerini etkilediğini belirtmiştir. Öğrenenlerin programlamaya ilişkin ilk akıllarına gelen özellik ve uygulamalarla ilgili alg1 ve görüşlerinden bazıları şu şekildedir:

"Karakter çizebilmek, ses kayıtı yapabilmek, kostümlere girip kediyi hareket ettirmek" [S1-7].

"Oyun ve animasyon yapmak ve Scratch programı" [S2-2].

"Çizgi film yapmak oyun yapmak" [P1-1].

"İstediğimi animasyon yapabilmek" [ P1-4].

"Bu derste yapılmış programlardaki hataları bulmayı çok sevdim. Polisiye iş yapar gibiydi" [S2-4].

Öğrenenlerin programlamaya ilişkin ilk akıllarına gelen özellikler ve uygulamaların animasyon, çizgi film yapmak, karakter çizmek gibi görsel ögeler olduğu görülmektedir. Programlama öğrenmenin neleri değiştirdiğini ise öğrenenlerden bazıları şu şekilde ifade etmiştir:

"Bilgisayarda yapabileceğim şeyler olduğunu gördüm" [S2-3].

"Bir sürü yeni şey öğrendim. Bilgisayar bilgisi öğrendim" [ P1-1].

"Kendimizin bir şeyler yapabilmesine uygun olmasını sevdim" [S2-1].

"Programlama "kukla oynatma"ya benziyor çünkü komutlarla her şeyi vermen lazım. Kapsamlı düşünmeyi öğretti bana” [P1-3]. 


\section{Programlama Süreçlerinin Öğretilmesine Yönelik Öğretim Programının Uygulama Sürecinde Öğrenenlerin Derse Katılımı Nasıldır?}

Araştırmanın ikinci araştırma sorusuna yönelik içerik analizi ile oluşturulan kodlar ve temalar Tablo 5'te verilmektedir. Ayrıca dikkat çekici görüşler kodlarla birlikte aynen sunulmuştur.

Tablo 5

Öğrencilerin Katılımı

\begin{tabular}{lll}
\hline Tema & Kodlar & Kodlama Sayısı \\
\hline & Davranışsal katılım & 18 \\
\cline { 2 - 3 } & Derse devam & 17 \\
\cline { 2 - 3 } & Sorulara cevap verme & \\
\cline { 2 - 3 } & Duyuşsal katılım & 36 \\
\cline { 2 - 3 } Katılım & Memlilik & 20 \\
\cline { 2 - 3 } & Öğrenci-öğrenci etkileşimi & 20 \\
\cline { 2 - 3 } & Öğrenci-öğretmen etkileşimi & 18 \\
\cline { 2 - 3 } & Diş çevre etkileşimi & 16 \\
\cline { 2 - 3 } & İsteksizlik & 5 \\
\cline { 2 - 3 } & Bilişsel katılım & 45 \\
\cline { 2 - 3 } & Uygulamalarda fikir üretme çabası gösterme & 43 \\
\cline { 2 - 3 } & Problem çözümleri üretme & 15 \\
\cline { 2 - 3 } & Ders dişı çalışmalar için zihinsel çaba harcama & \\
\hline
\end{tabular}

Tablo 5'teki veriler dikkate alındığında, katılımcıların bilişsel açıdan derse katılım boyutunun ağır bastığı görülmektedir. Katılımcılar tüm katılım boyutlarıyla ilgili olarak temelde öğrenme ortamında öğrenen öğretmen çevre etkileşiminin ve fiziksel çevreden kaynaklanan nedenlerin ve sınıf mevcudunun önemli olduğunu dile getirmiştir. Duyuşsal katılım alt teması altında yer verilen katılımcıların istek ve isteksizliği, süreçten memnuniyeti, etkileşim yönleri incelenmiştir. Bu konuda bazı katılımcıların görüşleri şu şekildedir:

“Scratch’te değişik komutları denemek için çok istekliyim” [S2-2].

"Bilgisayar dersi çok güzel geçiyor. Pazartesi gelsin diye heyecanlanıyorum" [P1-3].

Etkileşim yönleriyle ilgili bazı katılımcı görüşleri ise şöyledir: (ÖğrenciÖğretmen)

"İnternette proje örnekleri buldum. Kodlarına baktım. Kendi algoritmamı oluşturdum. Takıldığım yerleri öğretmenime sordum. Öğretmenim çok yardım etti” [S1-6]. 
"Su döngüsünü anlatan siteleri okudum. Sorular çıkardım. Sorularıma uygun resimler aradım. Bulamadıklarımda öğretmenim yardımcı oldu” [S2-4].

"Proje için plan yaptım. Hangi hafta ne yapacağımı belirledim. Özellikle öğretmenimden yardım aldım” [S1-8].

“Bazı zorluklarla karşılaştım. Nasıl yorum yapacağım gibi. Ama öğretmenime sorarak bu zorlukları yendim" [P1-2].

“Zorlandığım şeyler oldu. Ama arkadaşlarım da bilmediğinden öğretmenime sordum" [S2-2].

Öğrenenlerin dönem boyunca soru sorma, proje konusu belirleme, yardım talebi, problem çözme nedenlerinden dolayı öğretmenle çok sık etkileşim içinde bulunduğu söylenebilir.

Öğrenci-öğrenci arasındaki etkileşime ilişkin bazı görüşler şöyledir:

"Farklı sınıflardan arkadaşlarım da vardı. Farklı sınıftaki arkadaşlarımız bana çok yardımcı oldu" [P1-1].

“(Proje hazırlarken) Arkadaşlarıma internet kafedeki abime ne yapabileceğimi sordum.(...)" [S1-6].

"Onların denemediklerini denedim ve onlara yol gösterdim. .[S3-5]”, "Ben sadece bu dersteki değil sınıfımdaki arkadaşlara katkı sağlamak için hikayemi yazıp çizgi film yapacağım” [S3-3].

Dış dünya ile gerçekleşen etkileşime dair bazı görüşlerde öğrenenler etkileşimde bulundukları kaynakları şu şekilde ifade etmiştir:

"Problem çözme sürecine ihtiyacımız olan şeyleri belirleyerek başlarız. Sonra ne yapacağımıza karar veririz ve problemi çözeriz, çözemezsek annemize sorarız" [S1-5].

“Türkiye'nin illerinin konumu ve neyle ünlü olduklarını öğrenmek için proje yaptım. Öğretmen olan annemden konu belirlemede yardım aldım ve nasıl yapacağımı sordum" [S3-4].

"Evde kardeşim hep oynadığı için top sektirme oyunu projesi aklıma geldi. Yaparken çok zorlandım ama hem kardeşim hem de öğretmenim yardımcı oldu" [P1 2].

"Program kurulumu yapılan dönemin ilk haftasında annem gelip öğretmenime sordu. Evde annem babam hepimiz uğraştık” [P1-1].

"Arkadaşlarıma, abime ne yapabileceğimi sordum" [S3-3].

Öğrenenin arkadaşları ve öğretmeni dışında etkileşimde bulunduğu birçok kaynaktan kodlama sıklığına göre öne çıkan kaynak ailedir. 
Davranışsal katılım alt teması altında bazı katılımcılar öğrenme ortamının esnek katılıma izin veren şekilde olduğunu şu ifadelerle belirtmiştir:

"Ortamımız denemeye uygundu. Kıpırdama kalkma gibi kurallar yoktu. Arkadaşlarımın denemediklerini denedim ve onlara gösterdim” [ S3-5]. $1]$.

"Sınıfın kalabalık olmadığından daha rahatım. Daha rahat konuşuyorum” [P1-

"Bu derste farklı arkadaşlarla tanıştım. Sınıf kalabalık değildi. Sınıf çok rahattı. Derste istediğimiz fikirleri söyleyebildik. Öğretmenimizi çok sevdik. Tek başıma bilgisayarı kullanma cesareti kazandım” [S3-5].

Süreçte başta çekingen davranan öğrenenlerin sürece alışmaları kısa sürmüştür. Bunda öğretmene ve arkadaşlarına karşı oluşturdukları bakışın ve sınıf mevcudunun az olmasının da etkili olduğu söylenebilir. Bilişsel katılım alt temasında toplanan görüşler şöyledir:

"Dönem boyunca arkadaşlarımla fikirlerimi paylaştım. Onlar da bana birçok konuda yardım ettiler. İlk başlarda utangaçtım. Fakat arkadaşlarımı ve öğretmenimi sevdikçe bu düşüncemin gereksiz olduğunu anladım” [S2-6].

“(...) Öğrencilik hayatımda en eğlendiğim ders oldu. Kendimi çok rahat hissettim. Çünkü istediğim şekilde uygulama yapabildim. Arkadaşlarıma soru sorup fikirlerimi istediğim gibi paylaşabildim. Sınıftaki öğretmenimiz derste yerimizden kalkıp kalem açmamıza bile kızıyordu. Ama bu derste arkadaşlarımın ne yaptığına bakmak için özgürce dolaştım sınıfta. (...) Dersin güçlü yönü istediğim şekilde davrandığımız bir sınıfta olmam, istediğim fikri paylaşıp bunu uygulayabilmem oldu. (...)” [S3-4].

“(...) Hepimiz fikir ürettik. Sınıfta tartıştık. Başta herkes tek başına çalışıyordu. Arkadaşlarımdan çekiniyorduk. Daha sonra alıştık.(...)" [S1-8].

Programlama Süreçlerinin Öğretilmesine Yönelik Öğretim Programının Uygulama Sürecinde Öğrenenlerin Güdülenme Durumunu Etkileyen Faktörler

Araştırmanın üçüncü araştırma sorusuna yönelik içerik analizi ile oluşturulan kodlar ve temalar Tablo 6 ve Tablo 7'de verilmektedir. Ayrıca dikkat çekici katılımeı görüşleri kodlarla birlikte sunulmuştur.

Öğrencinin kendisinden kaynaklanan durumlar. Öğrenenlerin güdülenme durumlarını ortaya koymak için öncelikle katılımcıların süreçteki duygu ve tepkileri ele alınmıştır. Öğrenenlerin kendisinden kaynaklanan durumlar altında yer alan kodlar ve kodlanma sıklıkları Tablo 6'da verilmiştir. 
Tablo 6

İcsel Durumlar

\begin{tabular}{llc}
\hline Tema & Kodlar & Kodlama Sayıs \\
\hline & Olumlu durumlar & \\
\cline { 2 - 3 } & Beğeni & 139 \\
\cline { 2 - 3 } & Eğlenceli-mutlu & 46 \\
\cline { 2 - 3 } & Çaba gösterme & 18 \\
\cline { 2 - 3 } & Beklenti & 18 \\
\cline { 2 - 3 } İçsel Durumlar & Ḣi çekici bulma & 15 \\
\cline { 2 - 3 } & Heğecan & 11 \\
\cline { 2 - 3 } & Olumsuz durume & 5 \\
\cline { 2 - 3 } & Üzüntü & 5 \\
\cline { 2 - 3 } & Utanma-çekinme & 4 \\
\cline { 2 - 3 } & Sevmeme- beğenmeme & 5 \\
\hline
\end{tabular}

Tablo 6 incelendiğinde yazılım geliştirme sürecinin öğretiminde katılımcıların güdülenme düzeyinin içsel durumları belirlerken $139 \mathrm{kez}$ (en sık) kodlanan kodun "beğeni" olduğu görülmüştür. Elde edilen görüşlere göre yazılım geliştirme süreçlerinin, öğretiminin gerçekleştiği 15 haftalık zaman diliminde öğrenenlerin eğlenceli-mutlu, isteklilik, memnuniyet, çaba gösterme gibi duygu ve görüşlerinin yoğunluğu dikkat çekmektedir. Bununla ilgili görüşler şu şekildedir:

"Ben bu dönem ilk defa bilgisayar dersi aldım. Başta bilgisayar öğreneceğim diye çok heyecanlıydım. Bilgisayarı öğrendikçe mutlu olmaya başladım. Dersler çok eğlenceli geçti. Dersimizde renkler, sesler, animasyonlar vardı. Dönem sonunda iyi ki bu dersi almışım diyorum.(...)" [S2-5].

"Öğrenenler Scratch ile yapılmış oyunları görünce programı öğrenmeye daha çok motive oldular. Ayrıca öğrenenlerin çevrim-içi ortamda "çevrim-içi olanlar" listesinde isimlerini görmek çok hoşuna gitti” [Alan notu-03/03/2015].

"Resim yapmayı çok seviyorum bu yüzden hikaye kartı çizmeyi çok sevdim. (...) Web sitesinde bana ait şifremin olması çok güzel" [P1-4].

"Bu ders okul dersleri dışında güzel zaman geçirmesi için bir firsat verdi. Dersi çok seviyor ve o kadar ciddiye alıyorum ki her yapılanı. Bilgisayar dersi olduğu gün okula daha mutlu gidiyorum.(...)" [S3-2].

“(...)Ama çok güzel bir ders geçirdim bu dönem. Seneye tekrar olsun isterim” [S3-4].

$\mathrm{Bu}$ görüşlere göre öğrenenlerin derse karşı güdülenmelerini arttıran kendilerinden kaynaklı nedenlerin ilgi alanlarını derste kullanabilme, kendilerine özel tasarlanmış bir web ortamı ve kişisel hesaplarının olması, ders içinde gerçekleştirilen uygulama ve araçların özellikleri olduğu söylenebilir. Öte yandan aşağıdaki görüşlerden yola çıkılarak öğrenenlerin sürece ilişkin beklentileri ve başarı 
isteklerinin de güdülenmelerini arttığı görüşüne varılabilir. Bu durumu bir öğrenci şu şekilde açıklamıştır:

“Scratch'i öğrendim ve çok beğendim. Hiç zorlanmadım ve hakkında pek çok şey araştırdım. Geleceğin programcısı olacağım. Gelecek hayalim bunlar” [P1-4].

Bazı katılımcılar bir şeyler üretme ve başarı isteğini şu şekilde dile getirmiştir:

“Abim 6. Sınıfta. O da okulda aynı programı öğrendi. Dönem sonunda o benim gibi oyun hazırlayamadı. Ben daha çok şey öğrendim. Bazen ben abime öğrettim(:)" [S1-5].

"Bazı oyunların nasıl yapıldığını anladım. Evde boş boş bilgisayarla uğraşmıyorum artık. Annem babam da oyun yaptığımı görünce bana kızmıyorlar" [S3-3].

"Herkesin çalışmamı farklı yerlerden görebilecek olması çok güzel” [S1-8].

Süreçte bilişim teknolojileri dersine karşı ilgisiz olan, korkan, çekinen, bilişim teknolojilerini oyun oynama aracı olarak gören öğrencilerin güdülenmelerini arttığı söylenebilir. Aynı doğrultuda veliler de uygulama sırasında bilişim teknolojileri dersine karşı öğrencilerin güdülenmelerinin arttığından söz etmiştir. Öte yandan sürece ilişkin görüşlerden hareketle sürecin eğlenceli görüldüğü, süreçte yer alan uygulama, ortam, araç ve gereçlerin öğrenenler tarafından sevildiği söylenebilir.

Çalışmada katılımcıların Scratch programı ile programlama öğretiminde güdülenmelerini arttıran bir diğer önemli durumun da oyun ve çizgi film hazırlama isteği olduğu dikkat çekmektedir. Bu durumla ilgili bazı katılımcı görüşleri ise şu şekildedir:

"Bu programda çizgi film yapabileceğimi düşününce çok mutlu oldum” [P1-2].

"Hep hayalim kendi oyunumu yapabilmekti" [S1-5].

"Çizgi film yapmak için bize firsat sunuyor. Facebooku kuran bile bu programı kullanmamızı istiyor" [S1-3].

Katılımcıların duygu ve tepkilerinden yola çıkılarak süreçte "üzüntü, utanmaçekinme, korku" gibi güdülenmelerini olumsuz etkileyen durumların yaşandığ söylenebilir. Öğrenme sürecinde olumsuz duygu ve tepkiler gösteren öğrenenlerin ifadeleri şu şekildedir:

"Türkçe kitabımdan küçük su damlasının macerasını seçtim. Projeme başladım. Flash diskim sınıfta çalındığı için son halini öğretmenime gösteremedim üzüldüm” [S2-3].

"Bu dönem bilgisayar dersinde yaptıklarımı şöyle sıralayacağım. Öncelikle programlamanın ne olduğunu, bilgisayarın da insanlar gibi dili olduğunu öğrendim. Videolar izledim. Bir sürü insan bilgisayarın dillerini öğrenmekle uğraşırken benim haberim bile olmadığına üzüldüm. (...)" [S2-2]. 
"Projemi öğretmenimle internette paylaştık. Projeme bakan, beğenen çok az kişi oldu ve ben üzüldüm. Yani ben baktığım projelere yorum yaptım, beğendim. Fakat benim projeme kimse böyle yapmadı" [S1-7].

“(...)Derste arkadaşlarım bana hiç soru sormadı. Benden yardım istemedi. Üzüldüm” [P1-4].

“Ders kısa geldi.gelecek sene de olsaydı. Üzüldüm.” [ P1-5].

"Bilgisayarı hiç bilmiyorum, ilk defa bilgisayar dersi alıyorum ve korkuyorum" [S3-2].

"Derste başta arkadaşlarıma öğretmenime soru sormaya utandım. Annem çekinmem gerektiğini söyledi” [S2-4].

"Başta herkes tek başına çalışıyordu. Arkadaşlarımdan çekiniyordum. Daha sonra kaynaştık" [S1-8].

Katılımcıların duygu ve tepkilerinden yola çıkılarak süreçte "üzüntü, utanmaçekinme, korku” gibi güdülenmeyi olumsuz etkileyen durumların ortama alışma, bilgisayar kullanmayla ilgili yetersizlik algısı, yapılan çalışmaların ve ürünlerin beğenilmemesi nedeniyle olduğu görülmektedir. Ayrıca süreçte beğenilmeyen ve istenmeyen durumlar ise şöyle ifade edilmiştir:

"Scratch'ın kod şekillerini ise sevmedim" [P1-2].

"Sevmediğim yön dersin kısa olması, bi de sınıfın soğuk olması. Çok üşüdüm ve dersi bazen dinleyemedim" [S1-2].

"Web sitesinde tanımadığım kişileri arkadaş edinmek istemiyorum” [S2-6].

Dışsal durumlar. Öğrenenlerin güdülenme durumlarını ortaya koymak için öğrencilerin duygu ve tepkilerinin yanı sıra dışsal durumlara da bakılmıştır. Öğrencilerin güdülenmelerini etkileyen dışsal durumlar altında yer alan kodlar ve bu kodların kodlanma sıklıkları Tablo 7'de verilmiştir.

Tablo 7

Dışsal Durumlar

\begin{tabular}{lll}
\hline Temalar & Kodlar & Kodlama Sayısı \\
\hline \multirow{4}{*}{ Dişsal Durumlar } & Proje sunumu & 9 \\
\cline { 2 - 3 } & Diş tepki-dersi almayan öğrenenler & 5 \\
\cline { 2 - 3 } & Diş tepki-aile & 2 \\
\cline { 2 - 3 } & Gelecek planı & 2 \\
\cline { 2 - 3 } & Diğer ders öğretmenlerinin tutumu & 2 \\
\cline { 2 - 3 } & Popülerlik & 2 \\
\hline
\end{tabular}

Tablo 7 incelendiğinde, yazılım geliştirme sürecinde katılımcıların güdülenmeyi etkileyen dış kaynaklı durumları belirlerken en sık kodlanan kodların "proje sunumu- 
güdülenme, dış tepki-dersi almayan öğrenenler, dış tepki-aile" olduğu görülmüşsür. Süreç sonunda yapılan proje sunumunun, süreçte öğrenenlerin güdülenme düzeyini arttırdığı görülmüştür. Bununla ilgili bazı öğrenen görüşleri şu şekildedir:

“(...)Yaptığımız çalışmalarımızı paylaştık. Yani hem sınıfta sunduk hem de bir sitede paylaştık. Herkesin çalışmamı farklı yerlerden görebilecek olması çok güzel” [S1-4].

“(...)Başta bilgisayar öğreneceğim diye çok heyecanlıydım. Bilgisayarı öğrendikçe mutlu olmaya başladım.(...) Sunum yapmamız çok güzel oldu. Çok heyecanlı bir gün yaşadım" [S2-5].

"Bu hafta öğrenenler toplu olarak proje çalışmalarını paylaştılar. Öğrenenler sunum esnasında çok heyecanlandılar. Sunum esnasında derse katılımı az olan bazı öğrencilere firsat sağlandı" [Alan notu-01/06/2015]. [S1-6].

"Dersin bitiminde sunum da olması heyecan yaptı. Derse daha istekli geldim"

"Öğretmenime ve sınıf arkadaşlarımıza anlatınca yaptıklarımızı anlatınca çok şaşırdılar. Çünkü bu yaptıklarımızı sadece bilgisayar mühendisleri yapar sanıyorlardı" [P1-5].

"Eleştireceğim şey yok. Çok şey öğrendim. Bir proje yapmak da beni çok mutlu etti. Arkadaşlarımın hepsi bana imrendi” [P1-6].

Öte yandan dersi almayan sınıf arkadaşlarının, sınıf öğretmenlerinin ve ailenin olumlu tepkileri öğrenenlerin güdülenme düzeyini arttırmaktadır. Dersin ve etkinliklerin değişik görülmesi ve bundan dolayı öğrenenlerin çevresinde popülerliğinin arttığı görüşleri de güdülenme üzerinde olumlu olmuştur:

“(...)Arkadaşlarım bu dersi aldığım için bana farklı baktılar. Popülerliğıim arttı. Sınıfta bilgisayar bozulunca öğretmenim bana sormaya başladı. Çünkü öğretmenim bilgisayar kullanmayı bilmiyordu" [S3-5].

"Ben sadece bu dersteki değil sınıfımdaki arkadaşlara katkı sağlamak için hikayemi yazıp çizgi film yapacağım" [ S1-8].

Gelecek planlarının öğrenenlerin güdülenmelerini etkilediği şu ifadeden anlaşılabilir:

"Scratchi öğrendim ve çok beğendim. Hiç zorlanmadım ve hakkında pek çok şey araştırdım. Geleceğin programcısı olacağım. Gelecek hayalim bunlar" [P1-4].

Ayrıca süreçte beğenilmeyen ve istenmeyen durumlara örnek olarak şu ifade sunulmuştur:

“(...)Proje sunumunda çok heyecanlı bir gün yaşadım. Ama bazı arkadaşlarımızın projelerini öğretmenimiz sundurmadı. O arkadaşlarımız üzüldü” [S2-5]. 


\section{Tartışma, Sonuç ve Öneriler}

$\mathrm{Bu}$ araştırma, ilkokul 2., 3. ve 4. sinıfta öğrenim gören üstün yetenekli öğrencilere Scratch destekli programlama süreçlerinin öğretilmesine yönelik tasarlanmış bir öğretim sürecine ilişkin öğrenci görüşlerini incelemeyi amaçlamaktadır. Araştırmada elde edilen bulgulara göre öğrencilerin programlamaya yönelik görüşlerinde "Scratch programının özellikleri, farklı problem çözüm yollarının denenmesi ve programlamanın diğer derslerden farklı görülmesi” kodları öne çıkmaktadır.

Üstün yetenekli öğrencilere yönelik düzenlenen programlama eğitim etkinliklerinin katılımı olumlu yönde etkilediği bulunmuştur. Araştırma sonuçlarına göre "davranışsal katılım" alt boyutunda "derse devam" kodunun, "duyuşsal katılım" alt boyutunda "isteklilik" kodunun, "bilişsel katılım" alt boyutunda ise "uygulamalarda fikir üretme çabası gösterme" kodunun öne çıktı̆̆ı görülmektedir. Shin, Park ve Bae'ye (2013) göre üstün yetenekli çocuklar, sosyallik eksikliğinden dolayı etkinliklere davranışsal katılım göstermekte zorluk yaşamaktadır. Scratch programının bir parçası olan çevrim-içi boyutu (http://scratch.mit.edu) işbirliği için önemli firsatlar sağlar (Yildiz-Durak, 2018c). Bu bağlamda, üstün yetenekli öğrencilerin derse davranışsal olarak katılım sağlamalarında Scratch programının özeliklerinin katkısı olduğu söylenebilir. Scratch, programlamayı öğrenmek için basit bir arayüze sabit blok tabanlı bir programlama aracıdır (Resnick ve diğ., 2009). Scratch programında programlama kavramlarını öğrenmek, problemlerin çözüm yollarını ifade etmek kolaydır (Siegle, 2009; Yildiz-Durak, 2018b). Bununla birlikte programlama öğretiminde yer alan zorlayıcı görevler, üstün yeteneklilerin düşünme becerilerini geliştirmek için uygun görülür (Yildiz-Durak ve Güyer, 2018). Scratch programının yapısal özellikleri sayesinde programlama dilinin karmaşı yapısı ile uğraşmak zorunda kalmayan öğrencilerin içeriğe daha iyi odaklanacağ düşünülmektedir. Bu durumun ise öğrencilerin bilişsel katılımlarını destekleyeceği düşünülmektedir. Nitekim Kirk ve diğ. (2000), ortalama öğrencilerle karşılaştırıldığında, üstün yetenekli öğrencilerin, problem tabanlı öğrenme etkinlikleriyle öğrendikleri bilgileri kullanarak daha yüksek akademik performans göstereceğini belirtmiştir. Üstün yetenekli öğrencilere eğitim veren eğitimcilerin ise, öğretim ortamının üstün yetenekli öğrencilere gerçek dünya sorunlarını keşfetmeye, yenilikçi ürünler yaratmaya ve üst düzey düşünme becerilerini öğrenmeye yetecek firsatlar sağlaması gerektiğini öne sürmektedir (Poftak, 1988; Renzulli ve Reis, 1997; Tomlinson, 2002; VanTassel-Baska ve diğ., 1988). Üstün yeteneklilerin eğitiminde bu öğrenme koşullarını sağlamak için Scratch programının etkili bir araç olduğu söylenebilir. Gelecek çalışmalarda Scratch programının üstün yeteneklilerin eğitiminde kullanılması ve programlama öğretimindeki etkisinin deneysel çalışmalarla test edilmesi önerilmektedir.

Scratch ile gerçekleştirilen programlama öğretim sürecinde içsel ve dişsal güdülenmenin sağlanması açısından sürecin olumlu yönde etkisi olduğu sonucuna varılmıştır. Öte yandan öğrenme sürecinde güdülenmesini etkileyen birçok faktör 
bulunmaktadır (Bembenutty ve Zimmerman, 2003). Bu nedenle programlama öğretim sürecinde kullanılan araç, yöntem ve öğrenen tepkileri ayrıntılı olarak incelenmiştir. Scratch programının görsellik, renk ve ses gibi çoklu ortam ögelerinin güdülenme üzerinde olumlu etkisi olduğu görülmektedir. Scratch'ın derslerde etkin bir şekilde kullanılmasında, programın öğretici özelliğinin ötesinde öğrenende merak uyandıran görsellik, renk ve ses öğelerinin etkisi olduğu açıktır. Lee (2011) tarafından onlu yaşların başındaki üstün yetenkli öğrencilerle yapılan programlama öğretim çalışmalarında eğitsel açıdan Scratch'ın yaratıcı çalışmaları geliştirmeye olanak tanıyan, eğlenceli, renkli ve farklı bir öğretim aracı olarak nitelendirildiği görülmektedir. Buradan yola çıkarak Scratch'1n programlama süreçlerinin öğretiminde kullanılmasının tercih edilme sebebi olarak programlamayı öğrenme merakını ve programlama öğrenmeye yönelik güdülenmeyi pozitif etkilediği gösterilebilir. Siegle (2009) üstün yetenekli öğrencilerin öğrenmeye yönelik güdülenmeyi sağlamak için multimedya ürünler, dijital hikayeler, dijital oyunların geliştirilmesi gerektiğini belirtir. $\mathrm{Bu}$ çalışmada ise öğrencilerin görüşleri incelendiğinde, öğrenenler programlama öğrenmenin bilgisayarda bir şeyler üretebilme özgüveni kazandırdığını düşünmektedir. Dolayısıyla öğrenenler programlama sürecine, ürün ortaya koyma süreci olarak bakmaktadır. Bu durumun da öğrencilerin programlamaya yönelik güdülenmelerini olumlu etkilediği düşünülmektedir. Buradan hareketle üstün yeteneklilerin katılımıyla gerçekleştirilecek programlama eğitiminde dijital hikaye, dijital oyunların oluşturulduğu proje geliştirme çalışmalarına ağırlık verilmesi önerilebilir. Örneğin, Wang, Huang ve Hwang (2014) tarafindan 7. sınıf üstün yetenekli öğrencilerle yapılan proje tabanlı öğrenme ortamının öğrencilerin programlama öğretimindeki başarılarına etkisini araştırmak için yapılan araştırmada oyun, animasyon hazırlamaya dayalı sürecin derse yönelik güdülenmelerini arttırdığı bulunmuştur.

\section{Kaynakça}

Albion, Peter R. (2016, 29 Sept - 2 Oct) If this is the second coming of coding will there be rapture or rejection? In: Australian Council for Computers in Education 2016 Conference (ACCE 2016), Brisbane, Australia.

Altun, A., and Mazman, S. G. (2012). Programlamaya iliş̧kin öz yeterlilik algısı ölçeğinin Türkçe formumun geçerlilik ve güvenirlik çalışması. Eğitimde ve Psikolojide Ölçme ve Değerlendirme Dergisi, 3(2), 297-308.

Azevedo, R. (2015). Defining and measuring engagement and learning in science: Conceptual, theoretical, methodological, and analytical issues. Educational Psychologist, 50(1), 84-94.

Balanskat, A., and Engelhardt, K. (2014). Computing our future: Computer programming and coding-Priorities, school curricula and initiatives across Europe. European Schoolnet. 
Bembenutty, H., and Zimmerman, B. J. (2003, April). The relation of motivational beliefs and self-regulatory processes to homework completion and academic achievement. Annual Meeting of the American Educational Research Association, Chicago, IL.

Bloom, B. S. (1976). Human Characteristics and School Learning. New York, NY: McGraw-Hill

Büyüköztürk, Ş. (2009). Veri analizi el kitabı. Ankara: Pegem Akademi Yayıncılık.

Einhorn, S. (2011). Microworlds, computational thinking, and 21 st century learning. Logo Computer System Inc, White Paper. Retrieved from http://www.microworlds.com/ on 06.10.2016.

Fairchild, A. J., Horst, S. J., Finney, S. J., and Barron, K. E. (2005). Evaluating existing and new validity evidence for the Academic Motivation Scale. Contemporary Educational Psychology, 30(3), 331-358.

Fessakis, G., Gouli, E., and Mavroudi, E. (2013). Problem solving by 5-6 years old kindergarten children in a computer programming environment: A case study. Computers \& Education, 63, 87-97.

Fredricks, J. A., Blumenfeld, P. C., and Paris, A. H. (2004). School Engagement: Potential of the concept. State of tehe Evidence. Rewiev of Educational Research. 7(4), 59-109.

Grover, S., and Pea, R. (2013). Computational thinking in K-12: a review of the state of the field. Educational Researcher, 42(1), 38-43.

Hansen, J. B., and Toso, S. J. (2007). Gifted dropouts: personality, family, social, and school factors. Gifted Child Today, 30(4), 30-41.

Harper, S. R., and Quaye, S. J. (2009). Beyond sameness, with engagement and outcomes for all. In S. R. Harper, and S. J. Quaye (Eds.), Student engagement in higher education (pp. 1-15). New York and London, NY and London: Routledge.

Havenga, M., and Mentz, E. (2009, June). The school subject information technology: a South African perspective. In Proceedings of the 2009 Annual Conference of the Southern African Computer Lecturers' Association (pp. 76-80). ACM.

Hongwarittorrn, N., and Krairit, D. (2010, April). Effects of program visualization (jeliot3) on students' performance and attitudes towards java programming. In The spring 8th International conference on Computing, Communication and Control Technologies (pp. 6-9). Orlando, FL, USA.

Jenkins, T. (2002). On the difficulty of learning to program. In Proceedings of the $3 r d$ Annual Conference of the LTSN Centre for Information and Computer Sciences, 4(2002), 53-58. 
Jones, R. D. (2008). Strengthening student engagement. author and senior consultant, international center for leadership in education. Retrieved from http://www.leadered.com/pdf/Strengthen\%20Student\%20Engagement\%20whit e\%20paper.pdf.

Kalelioğlu, F., and Gülbahar, Y. (2014). The effects of teaching programming via scratch on problem solving skills: A discussion from learners' perspective. Informatics in Education, 13(1), 33-50.

Kalelioğlu, F. (2015). A new way of teaching programming skills to K-12 students: Code. org. Computers in Human Behavior, 52, 200-210.

Kim, K. Y., Song, J. B., and Lee, T. W. (2009). Effect of digital storytelling based programming education on motivation and achievement of students in elementary school. Journal of the Korea Society of Computer and Information, 14(1), 47-55.

Kirk, S., Gallagher, J. J., and Anastasiow, N. (2000). Educating exceptional children (9th ed.). Boston, MA: Houghton-Mifflin.

Koorsse, M., Cilliers, C., and Calitz, A. (2015). Programming assistance tools to support the learning of IT programming in South African secondary schools. Computers \& Education, 82, 162-178.

Lau, W. W., and Yuen, A. H. (2011). Modelling programming performance: Beyond the influence of learner characteristics. Computers \& Education, 57(1), 1202 1213.

Law, K. M., Lee, V. C., and Yu, Y. T. (2010). Learning motivation in e-learning facilitated computer programming courses. Computers \& Education, 55(1), 218228.

Lee, Y. J. (2011). Scratch: Multimedia programming environment for young gifted learners. Gifted Child Today, 34(2), 26-31.

Lye, S. Y., and Koh, J. H. L. (2014). Review on teaching and learning of computational thinking through programming: What is next for $\mathrm{K}-12$ ? Computers in Human Behavior, 41, 51-61.

Manovich, L. (2013). Media after software. Journal of Visual Culture, 12(1), 30-37.

Middleton, J., and Spanish, P. (1999). Motivation for achievement in mathematics: Findings, generalizations and criticism of the research. IRME Online,30(1), 6588.

Miles, M. B., and Huberman, A. M. (1994). Qualitative data analysis. London: Sage. 
Moreno-León, J., Robles, G., and Román-González, M. (2016). Examining the relationship between socialization and improved software development skills in the scratch code learning environment. J. UCS, 22(12), 1533-1557.

National Research Council (2003). Engaging schools: fostering high school students' motivation to learn. Washington, DC, USA: National Academies Press.

National Research Council. (2012). A framework for K-12 science education: Practices, crosscutting concepts, and core ideas. National Academies Press.

Partnershipfor 21st Century Skills (P21). (2007). Partnership for 21st Century Skills. Retrieved from http://www.p21.org/about-us/p21-framework/60.

Poftak, A. (1998). Technology and gifted education: A talk with Carol Wilson. Technology \& Learning, 19(4), 14-14.

Popat, S., and Starkey, L. (2019). Learning to code or coding to learn? A systematic review. Computers \& Education, 128, 365-376.

Reis, S. M., and Renzulli, J. S. (2009). Myth 1: The gifted and talented constitute one single homogeneous group and giftedness is a way of being that stays in the person over time and experiences. The Gifted Child Quarterly, 53(4), 233-235.

Renzulli, J. S., and Park, S. (2000). Gifted dropouts: The who and the why.Gifted Child Quarterly, 44(4), 261-271.

Renzulli, J. S., and Reis, S. M. (1997). The schoolwide enrichment model: A how-to guide for educational excellence. Creative Learning Press, Inc., PO Box 320, Mansfield, CT 06250.

Resnick, M., Maloney, J., Monroy-Hernández, A., Rusk, N., Eastmond, E., Brennan, K., ...Kafai, Y. (2009). Scratch: programming for all. Communications of the ACM, 52(11), 60-67.

Rushkoff, D. (2010). Program or be programmed: Ten commands for a digital age. New York, NY: O/R Books.

Ryan, R. M., and Deci, E. L. (2000). Intrinsic and extrinsic motivations: Classic definitions and new directions. Contemporary Educational Psychology, 25(1), 54-67.

Senemoğlu, N. (2009). Gelişim öğrenme ve ögretim kuramdan uygulamaya. Ankara: Nobel Yayınevi.

Sönmez, V. (1997). Sosyal bilgiler ögretimi ve öğretmen kllavuzu. Ankara: Anı Yayıncilik.

Shin, S., Park, P., and Bae, Y. (2013). The effects of an information-technology gifted program on friendship using scratch programming language and clutter. International Journal of Computer and Communication Engineering, 2(3), 246249. 
Siegle, D. (2009). Developing student programming and problem-solving skills with Visual Basic. Gifted Child Today, 32(4), 24-29

Swan, K. (2001). Virtual interaction: Design factors affecting student satisfaction and perceived learning in asynchronous online courses. Distance Education, 22(2), 306- 331 .

Tomlinson, C. A. (2002). The parallel curriculum: A design to develop high potential and challenge high-ability learners. London: Corwin Press.

Tomlinson, C. A., Kaplan, S. N., Renzulli, J. S., Purcell, J. H., Leppien, J. H., Burns, D. E., and Imbeau, M. B. (2008). The paralel curriculum: A design to develop learner potential and challenge advanced learners. London: SAGE.

Topalli, D., and Cagiltay, N. E. (2018). Improving programming skills in engineering education through problem-based game projects with Scratch. Computers \& Education, 120, 64-74.

Wagner, E. D. (1998, August). Interaction strategies for online training designs. Proceedings of the Annual Conference on Distance Teaching and Learning (pp. 417-420), Madison, WI.

Wang, H. Y., Huang, I., and Hwang, G. J. (2014). Effects of an Integrated Scratch and project-based learning approach on the learning achievements of gifted students in computer courses. Retrieved from http://ieeexplore.ieee.org/xpl/login.jsp?tp=\&arnumber=6913329\&url=http\%3A $\%$ 2F\%2Fieeexplore.ieee.org\%2Fxpls\%2Fabs_all.jsp\%3Farnumber\%3D691332 9.

Wilson, A. Connolly, T.M. Hainey, T., and Moffat, D. (2011, October). Evaluation of Introducing Programming toYounger School Children Using a Computer Game Construction Application, Proceedings of 5th European Conference on Gamesbased Learning (ECGBL), Athens, Greece.

Wing, J. M. (2006). Computational thinking. Communications of the ACM, 49(3), 33 35.

VanTassel-Baska, J. (1988). Curriculum design issues in developing a curriculum for the gifted. In: J. Van Tassel-Baska, J. Feldhusen, K. Seeley, G. Wheatly, L.Silverman and W. Foster (Eds), Comprehensive curriculum for the gifted learners, (pp. 55-76). Boston, MA: Allyn and Bacon.

Valasek, T. (2001). Student persistence in web-based courses: Identifying a profile for success. New Jersey, NJ: Raritan Valley Community College Center for the Advancement of Innovative Teaching and Learning. ERIC Document No. 466276. 
Yen, C.-Z., Wu, P.-H., and Lin, C.-F. (2012). Analysis of expert's and novice's thinking process. Engaging Learners through Emerging Technologies, Communication in Computer and Information Science, 302, 122-134.

Yıldırım, A., ve Şimşek, H. (2013). Sosyal bilimlerde nitel araştırma yöntemleri. Ankara: Seçkin.

Yin, R.K. (2003). Case study research: Design and methods. London: SAGE.

Yildiz-Durak, H. (2018a). Digital story design activities used for teaching programming effect on learning of programming concepts, programming selfefficacy, and participation and analysis of student experiences. Journal of Computer Assisted Learning. 34(6), 740-752.

Yildiz-Durak, H. (2018b). Flipped learning readiness in teaching programming in middle schools: Modelling its relation to various variables. Journal of Computer Assisted Learning. 34(6), 939-959.

Yildiz-Durak, H. (2018c). The effects of using different tools in programming teaching of secondary school students on engagement, computational thinking and reflective thinking skills for problem solving. Technology, Knowledge and Learning, 1-17. doi: 10.1007/s10758-018-9391-y.

Yildiz-Durak, H., and Güyer, T. (2018). Design and development of an instructional program for teaching programming processes to gifted students using scratch. In J. Cannaday (Ed.) Curriculum development for gifted education programs (pp. 61-99). Hershey: IGI Global. 
Ankara University Journal of Faculty of Educational Sciences

Year: 2019, Volume: 52, Issue: 1, 107-137

DOI: 10.30964/auebfd.466922, E-ISSN: 2458-8342, P-ISSN: 1301-3718

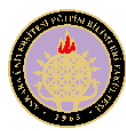

\title{
An Investigation of the Opinions of Gifted Primary School Students' in the Programming Training Processes $^{1}$
}

\begin{tabular}{cccc}
\hline ARTICLE TYPE & Received Date & Accepted Date & Online First Date \\
Research Article & 10.03 .2018 & 01.09 .2019 & 01.13 .2019 \\
\hline
\end{tabular}

\author{
Hatice Yıldız Durak \\ Bartın University
Tolga Güyer iD 3
Gazi University

\begin{abstract}
Teaching programming at an early age has become popular. The aim of this study is to examine the participant views for the teaching of Scratch-supported programming processes to the 26 gifted students studying at the 2nd, 3rd and 4th grades of primary school. Additionally, students' opinions on learning materials, tools and processes are examined in detail. In this case study, five different tools were used to collect qualitative data. In this study, a questionnaire, semi-structured personal interview form, field notes and student reflection reports were used to collect qualitative data.One of the highlights of the study is that the visual, colour and sound elements of the Scratch program have positive effects on motivation and course participation. In addition, , students who have negative attitudes towards computer lessons at the beginning of the course have changed their attitudes at the end of the process. Looking at the types of motivation that direct students, it can be observed that the intrinsic and extrinsic motivation elements have similar effects on the success, lesson participation and behaviours of the learners.
\end{abstract}

Keywords: Gifted students, scratch, programming in K-12, participation; motivation.

\footnotetext{
${ }^{1}$ This study is derived from the $\mathrm{PhD}$ thesis titled "Design and development of an instructional program for teaching programming process to gifted students", conducted by Hatice Durak in Gazi University, Institute of Educational Sciences, Department of Computer Education and Instructional Technology, under the supervision of Professor Tolga Güyer.

${ }^{2}$ Corresponding Author: Assist. Prof., Faculty of Education, Computer Education and Instructional Technology, E-mail: hatyil05@gmail.com, https://orcid.org/0000-0002-5689-1805

${ }^{3}$ Prof., Faculty of Education, Computer Education and Instructional Technology, E-mail: tguyer@gmail.com, https://orcid.org/0000-0001-9175-5043
} 
When it comes to programming training, the target group is generally students who are studying in higher education. However, along with various applications for the acquisition of 21 st-century qualifications in education, programming education has started to be seen as important for secondary school and even for primary and kindergarten students. Programming education is particularly seen as functional in the acquisition of skills called as 21 st century skills like "creativity, critical thinking and problem solving, communication and collaboration, social and intercultural skills, productivity and responsibility, leadership and responsibility. Because the programming processes involve different thinking skills and knowledge areas, they allow kids to develop skills such as "communication skills, creativity, intellectual curiosity, critical and systematic thinking, interpersonal and collaboration skills, problem identification, formulating and solving, self-direction" which are already in the nature of the programming process. In other respects, programming skills can be seen to have become the basic skills of 21 st century. Based on these opinions, a study on programming education in primary schools has been decided to be conducted. Gifted students have been chosen as the target audience as the improvement of their potentials were thought to be made more effectively with programming trainings. However, there is no Information Technologies (IT) curriculum for gifted students or others in primary school level in Turkey. The existing conditions in this regard show that there is no standard application for the trainings to be given within the scope of the "support training room" practice organised beyond the common formal education for the gifted students and made compulsory by the Ministry of National Education. The practices applied during the IT courses that are among the ones offered in the support room are differing from school to school. A lack of a curriculum becomes remarkable while applying such practices. For this reason, within the scope of the study, primarily a curriculum development program for programming training has been carried out. The participants' participation and motivation levels were focused on to examine the integration process of this curriculum.

\section{Purpose and Significance}

The aim of this study is to examine the participant views in the teaching of Scratch-supported programming processes to the gifted students studying at the 2nd, 3rd and 4th grades of primary school. In this direction the sub-problems below were defined:

1. What are the opinions of learners on programming during teaching programming processes?

2. How is the participation of learners in the courses (behavioural, affective and cognitive participation) during teaching programming processes?

3. What are the factors that influence the motivation of the learners in the teaching programming processes? 


\section{Method}

The case study, one of the qualitative research methods, is used in this study for examining in depth the participant's views on the point of their views, participations and motivations during the integration process of the curriculum for teaching Scratchsupported programming processes.

This study was carried out with 26 students who were decided to receive extracurricular education through the application of support education room in the 2nd, 3rd and 4th grades.

\section{Results}

It is seen that the participants use the Scratch program in the programming teaching process as "different, instructive and multifaceted". In addition, When the learners were asked the qouestion during the interviews that "What can you say about Scratch?", the, the learners emphasized that the Scratch program was a surprising and extraordinary learning tool with a visual, color, flexibility to control, quality and sometimes complex and strange features. It is observed that the participants' participation in the classroom is dominant. Participants expressed that, in relation to all the participation dimensions, the learning environment in the learning environment is mainly important for the learning environment and the reasons of physical environment and the class size. While the motivation of the participants in the software development process was determined by the students, it was seen that the code coded 139 times (the most common) was the software appreciation. According to the opinions obtained, it is noteworthy that in the 15 -week period during which software development processes are taught, the intensity of emotions and opinions of the learners such as fun-happy, willingness, satisfaction and effort are noteworthy. The most frequently coded codes in the software development process that determine the extrinsic situations affecting the participants' motivation were "project presentation-motivation, external reaction-learning, external response-family. The project presentation at the end of the process increased the motivation of the learners in the process.

\section{Discussion and Conclusions}

Motivation, class attendance and participation have an important place under the factors affecting teaching. For this reason, all kinds of tools and learners' reactions used in the teaching process are examined in detail. Beyond the instructional feature of the program, it is clear that the effect of visuality, color and sound elements that are intriguing in the learners are the effects of the program. In a study conducted in the literature, it is noteworthy that in the study of programming concepts for 8/9 yearold learners, with the help of Scratch, the learners enjoyed the process and participated in the process effectively. Similarly, in a study of teaching programming conducted by Lee (2011) with students in their early teens, it is seen that Scratch is described as an entertaining, colourful and a different teaching tool that enables the development of creative works. From this point of view, the reason why Scratch is used in teaching 
software development processes can be shown as the curiosity to learn programming and its positive affect on learning programming in terms of attitudes, motivation and participation.

It has been found that the learning environments designed in the integration process of the program developed for gifted students have a positive effect on student participation. The most important reason for this situation to provide the richness of the tools with active learning activities in the learning environment and to offer activities in face-to-face activities as well as in web-based environments.

It is seen that the visual, color and sound elements of the Scratch program have a positive effect on motivation and class participation. On the other hand, the attitudes of the students who have negative attitudes towards computer lesson at the beginning of the course have changed. Since there is no prior knowledge and experience of programming, there is no perspective on this subject. These students, who feared using computers, viewed the computer as a game tool, developed a positive attitude towards the computer through programming trainings, and these students' viewpoints changed positively. In this study, it is seen that the motivation elements of internal and external motivations have similar effects on the success, attendance and behavior of the learners. 